\title{
Sociolinguistic approaches to identity negotiation and language learning: A circumstantiality perspective on communities of practice
}

\author{
Jou, Yu Shiang $\bigotimes$ \\ National Taiwan University, Taiwan (yushiangjou@ntu.edu.tw)
}

Received: 23 March 2012

Available Online: 5 June 2012
Revised: 14 May 2012 DOI: $10.5861 /$ ijrsll.2012.105

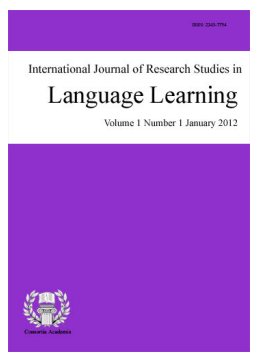

ISSN: 2243-7754 Online ISSN: 2243-7762

OPEN ACCESS

\section{Abstract}

As a result of growing globalization, the learning experience of second/foreign (L2/FL) language learners has been inextricably linked to complex social structures and networks. Through a sociolinguistic lens, this paper provides a critical review of L2/FL learning, identity negotiation, and community of practice in the face of incremental changes in linguistic systems and norms concomitant with gradual transformations in politics, society, and economics. In different social structures, identity emerges and is formed in complex social, cultural, and interactional phenomena. Due to the complicity of identity work, methods employed in identity and language learning entail both qualitative and quantitative approaches, including micro and macro analysis of language use, and ethnographic study on social and cultural practices. It is examined in this paper how identity has been conceptualized in sociocultural theories of language learning. Moreover, I probe into the context in which language learning takes place and discuss to what extent L2 and FL communities overlap and exchange. I argue for a perspective on the "circumstantiality" of language learning and communities of practice. At the end of this paper, reflections on identity work are offered and implications for language learning are discussed in the hope of relevant issues to be further explored.

Keywords: sociolinguistics; second and foreign language acquisition; language identity; lingua franca; postmodern globalization 


\section{Sociolinguistic approaches to identity negotiation and language learning: A circumstantiality perspective on communities of practice}

\section{Introduction}

Under the influence of postmodern globalization and its ensuing migration flows, bilingual or multilingual communities have become a kaleidoscope of different cultures. In view of social changes in this era of increasing globalization, identity work particularly involves individual's language learning process and has been of considerable interest in Second Language Acquisition (SLA). A growing body of identity research has suggested that language is well beyond the scope of linguistic codes (e.g., Block, 2006). Norton and Toohey (2002) aptly noted that

Language learning engages the identities of learners because language itself is not only a
linguistic system of signs and symbols; it is also a complex social practice in which the value and
meaning ascribed to an utterance are determined in part by the value and meaning ascribed to
the person who speaks. (p. 115)

Breen and Candlin (1980) assert that "language learning is learning how to communicate as a member of a particular socio-cultural group" (p. 90). From a sociolinguistic perspective, Heller (2007a) argues that language should be viewed as "a set of resources which circulate in unequal ways in social networks and discursive spaces" (p. 2). Thus, the exclusive focus on semiotic analysis would lead to inadequate consideration of learners' sociocultural identities critical to expanding their social repertoires. In seeing learning as interactive participation, language teaching professionals need to consider how school practices are associated with those outside of school. Since classrooms also develop into communities of practice, there is a need to understand how classroom communities cater to students, and what kinds of participation are made accessible to them. It is imperative to identify the kinds of interaction that facilitate student participation inside and outside the classroom (Zuengler \& Miller, 2006).

Building on Norton's (1995) line of argument, much identity research drew on poststructuralist theories of identity, with a focus on societal and cultural influences on the dynamics of linguistic communities, to further frame language teaching and learning (Menard-Warwick, 2005; Ricento, 2005; Block, 2007a, 2007b). Identity researchers, in order to understand the relationship between identity and language learning, have employed poststructuralist and sociocultural theories to progressively explicate how identity has been conceptualized in a multicultural society (Norton \& Toohey, 2011).

The mainstream SLA research has been cognitively and experimentally oriented. In this view, language learning is an individualized and autonomous process, internal linguistic construction and development in close focus. As a result of this dominant stream of research on linguistic competence, investigations into language performance have been peripherally discussed. As language is socially constructed and practiced, language use, in a sense, is socioculturally situated cognition, emerging in the dynamics of social constructions and negotiations. Using qualitative methodologies to interpret data, analysis of naturally occurring classroom interactions brings to light identity and language learning. Commonly lacking in identity research, however, is a deeper understanding of discourse that occurs outside the classroom (Duff, 2002; Block, 2007a).

SLA may differ from FLA in many respects (e.g., settings inside and outside the classroom). Yet the demarcation may blur when learners cross the borders engaging in both communities. This overlapping property manifests itself when language learning does not occur in a fixed context. Identity construction may be altered as such. Further, research on group identity suggests that identity research needs to be considered in intergroup relations and the relationship between intergroup networks (Kinginger, 2004). It is also this argument that I hope 
to refine in this article. This will be discussed at greater length later.

In order to examine the dynamics among identity, community, and language learning, a review on how identity has been conceptualized in SLA over the past few decades was accomplished. In light of the globalized use of languages, it was examined how globalization has changed the course of language learning. It is argued that distinctions in communicative contexts of English use are blurred across borders when English is used as a lingua franca (i.e., in situations where interlocutors belong to different sociolinguistic backgrounds). As a result, learners' learning experience may be influenced by this circumstantiality of the community in which they engage. It is hoped that such a perspective will help elucidate how identity work and SLA/FLA research can better map language learning onto pedagogical, social, and cultural landscapes that have changed considerably.

\section{The Conceptualization of Identity in Second Language Acquisition}

Studies of SLA have opened up different lines of research on L2 learning and development. SLA researchers have employed various methodologies to address a broad spectrum of topics that are multi-faceted in their applications. Many SLA theorists regard social variables (e.g., ethnicity, citizenship, gender, and class) as particularly relevant to language learning (see, for example, Gass \& Varonis, 1986). As identity is a discursive construct that emerges in interaction, some researchers have conceptualized social identity as a struggle of L2 learners to acculturate into the social world they inhabit (Peirce, 1995; Norton \& Toohey, 2002).

As early as Zuengler (1989), there has been a large body of research on identity and SLA conducted with respect to language socialization, multilingual identities, and negotiated identities in diverse languages, cultures, and social contexts (Norton, 2000; Toohey, 2000; Bayley \& Schechter, 2003; Pavlenko \& Blackledge, 2004; Block, 2006). As many sociolinguists argue (e.g., Bartlett, 2007; Hornberger, 2007), identities emerge on "trajectories across time and space" (Hornberger, 2007, p. 330). Moreover, identity researchers (e.g., Zuengler \& Miller, 2006) contend that sociocultural identity, in particular, helps paint a holistic portrait of language development as a socialization process, and communities and classrooms as complex ecological systems. Learners may come to understand and use language as competent participants in socially and culturally situated contexts of communication. For example, with adequate communicative competence in sociocultural contexts, they may well be able to actively participate in diverse sociocultural activities in which their identity is concurrently being shaped (e.g., in expanding their social circles both inside and outside the school or creating employment opportunities). As such, their learning and identity construction are not only housed in learners' mind, but they are also situated in their sociocultural contexts where interpersonal and intergroup interactions occur. In consideration of this, a series of separate identity categories should be examined under the same umbrella as macrocontextual aspects (e.g., social, political, and cultural factors) are de facto interconnected (Martin-Jones \& Heller, 1996). A conceptualization of identity in SLA has thus been developed calling for careful consideration of social and contextual factors.

In the field of sociolinguistics, identity is conceived as a complex and multifaceted construct occurring in dynamic interaction across temporal and spatial scales. That is, linguistic interactions construct identity and are constructed by language practice. As language and culture are hardly separable, issues of identity construction should be approached through a social and cultural lens. In different facets of educational and social practice, sociocultural identities are consistently constructed and negotiated. An increasingly bilingual and multilingual student body has also made identity work more integrated with ethnic and anthropological approaches that are multidimensional and dynamic in nature. In opposition to the prevailing cognitive view on SLA that language learning is individualized, functioning in a way that is independent of language use and its contexts, Kramsch (2002) maintains that conventional separation between language learning and sociocultural perspectives fails to consider language use in sociocultural contexts. Thus, some SLA researchers attempt to fuse cognitive and sociocultural perspectives in that cognition "originates in social interaction and is shaped by cultural and sociopolitical processes" (Watson-Gegeo, 2004, p. 331). As Norton (1995) argues, it is an integral part of SLA theories to conceptualize language learners and their learning contexts as having multimodal and multilateral 
identities in complex social structures and interactions.

\section{Methodologies in Identity Work and Language Learning}

Research on language learning, at the pragmatic level, views language as a resource for engagement in everyday activities (Larsen-Freeman, 2002; Zuengler \& Miller, 2006). Methodological and theoretical frameworks employed in identity research attempt to interpret distinct dimensions of social and cultural life of language learners. Some methodologies of language acquisition concern investigations into static linguistic competence (e.g., Pavlenko \& Blackledge, 2004), while others zoom in on transitional properties closely associated with the dynamic acquisition process (e.g., Larsen-Freeman, 1997; Dornyei \& Skehan, 2005).

At the microscopic level of discourse, functionally appropriate speech acts and conversational exchanges are a locus of discourse that serves the communicative function of language. Participants of different linguistic and cultural backgrounds, however, may have quite distinct perceptions of their participation in local language and literacy practices. Individual narratives about language learning have thus become particularly relevant. In identity research, it is vital to ensure the validity of naturally occurring spoken interaction that is audio recorded for transcription and analysis.

To examine identity categories (e.g., race, class, gender) relating to equality of opportunity and access to language acquisition and use, sociocultural linguists (e.g., Sacks, 1995; Murphy, 1997) invoked ethnography, anthropology, and poststructuralist theories to develop systematic methodologies. Due to its complexity and ecological validity, identity work may not be thoroughly examined resting on a single line of research. It calls for a matrix of theoretical enterprises and complementary methodologies drawing on qualitative and quantitative linguistic analysis, microanalysis of conversation, macroanalysis of ideology, and ethnographic study on social and cultural practices. Valid identity work entails the synergy of these methodologies that make it possible to piece together the holistic puzzle.

\section{Lingua Franca and Postmodern Globalization}

\subsection{Debate over Standard and Non-standard Varieties}

An a priori assumption in the second and foreign language teaching profession is that L2/FL learners are defective in communicative competence and that their learning is, on a conscious and unconscious level, pursuing the ought-to self in the hope of attaining native-like proficiency. The differential tag in favor of Standard English has made American and British English norms the most far-reaching varieties. This common stereotype has already been called into question. That a unitary standard variety is the only yardstick of language use is out of sync with contemporary reality. In bilingual and multilingual communities today, standard communication protocols could no longer serve the communicative demands of bilinguals and multilinguals in increasing need of both communicative and symbolic competence especially in intercultural communication (Kachru, 1992, 1997). Thus, to a considerable extent, the sociolinguistic reality of bilingual and multilingual communities has formulated constructs on a different footing.

\subsection{ELF and WE Paradigms}

Equivalent to English as an international language (EIL) in terms of its intrinsic meaning (cf. Canagarajah, 2006; McKay \& Bokhorst-Heng, 2008; Phan, 2008), English as a lingua franca (ELF) is defined as a communication tool between people of different linguacultures in English. ELF is spoken mainly by non-native speakers of English who may also develop non-native varieties of English (Firth, 1996). In Asia, for example, Bahasa Indonesia and Putonghua are used as lingua francas. Bahasa Indonesia is the national language in Indonesia, a mélange of more than 400 ethnic groups and more than 200 languages and dialects. Putonghua (also known as Mandarin Chinese) is the national and common language of China (Kirkpatrick, 2010, p. 4). The same 
Sociolinguistic approaches to identity negotiation and language learning

is true in Taiwan, where Mandarin Chinese is used as a lingua franca between people speaking Southern Min, Hakka, and various aboriginal dialects. Despite the growing influence and reach of Putonghua as a lingua franca in many Asian countries, English still remains the primary lingua franca in Asia, owing primarily to its mainstream education curricula (Li, 2006; McGroarty, 2006).

Many vernacular universals of non-standard features can also be found in almost every variety of English (e.g., the use of plural and other common grammatical features). The commonalities of many non-standard features across different varieties of English suggest that variables other than those coming from the speakers' L1 exist (Chambers, 2004). These universals may be derived from both contact-induced language changes (e.g., cultural and linguistic influence of L1 or other languages) and universal tendencies of different linguistic features (Thomason, 2009). Distinctive pronunciation features, in particular, can be clearly observed across different varieties of English. As such, ELF research has suggested that ELF is different from World Englishes (WEs) in that WEs may develop their own culturally specific use of vocabulary as well as the change of lexical meaning that conforms to local norms, while this may be rare in ELF (Kirkpatrick, 2010). Another distinctive feature is that WEs may contain much code-switching and code-mixing as a way to express a communal identity. According to Kachru and Nelson's (2006) survey of WEs, English varieties in East, South, and Southeast Asia include Chinese, Indian, Nepali, Pakistani, Philippine, Singaporean, and Singaporean-Malaysian English. Varieties in other regions of the world contain African, Australian, Caribbean, Mexican, and Nigerian English (i.e. Kachru's outer circle). When speakers share the same linguistic backgrounds, they also have common cultures and speech acts under the same identity label. However, this is less likely to occur in ELF communication as its primary goal is mutual intelligibility (Kirkpatrick, 2007; McLellan \& David, 2007).

At "The fourth international conference of English as a lingua franca (ELF4)" held in Hong Kong, Widdowson (2011) accentuated his notion of "only connect" in this increasing trend toward the global use of English and argued that:

I want to put ELF in broader perspective and explore how it raises general epistemological and practical issues in (socio) linguistics and language pedagogy. It is the wider implications of the ideas and findings of ELF study that I am concerned with here....Both of them [linguistics and language pedagogy] necessarily disconnect the continuum of actual experience to make simplifying distinctions so as to come to terms with reality.... Making distinctions of one kind or another is a necessary convenience and cannot be avoided, but having made them, we need also to consider how they are related. (p. 10)

The English language and the accepted protocol were largely in thrall to the language policies of political and educational contexts of post-imperial and post-colonial periods (Kachru, 1997). Different Englishes today, however, have contributed to theoretical formulations for linking identities and communities, and to the empirical investigation of these formulations in practice. It is now beyond dispute that the varieties in the Outer Circle communities have constructed their own sociocultural identities (cf. Kachru's three circle model, 1988, 1992). How communities are connected to make up the nexus of the local and the global communities has then been seminal in developing both the concepts of WEs and ELF. With the continuing challenge of monolithic English (e.g., Crystal, 2003) or "monochrome standard form" as Quirk puts it (1985, p. 6), that global social structures and language learners' identities are hardly separable is increasingly in evidence.

Deeply rooted in the English teaching profession was the Standard English (SE) paradigm that had been in existence before the concept of WEs. It was this firm conviction that informed the English curriculum and immersion programs launched in China, Korea, and Japan. Many academics (e.g., Quirk, 1990) argue in favor of native speakers of English and their legitimate identity as English speakers. This said, however, some conflicting findings in early SLA research (e.g., Dulay, et al., 1982; Goldstein, 1987) called into question the conventional assertion of SE and the 'wholesome' paradigm of it. As the debate over non-native varieties of English against SE grew heated, it has come to light that speakers of different English varieties also lay claim to their use of 
English and establish their legitimate sociocultural identities.

WEs and ELF paradigms and their conceptualizations of identity have thus been illuminated and expanded in parallel descriptive research. Identity work, as such, should be further investigated along with the social relationships in which non-native speakers of English engage and with their ability to interpret meanings in different contexts of communication. As Widdowson (1994) points out, "the language has been learned, not just as a set of fixed conventions to conform to, but as an adaptable resource for making meaning" (p. 384). In view of the sociolinguistic reality of the use of different varieties of English in international communication, the emergence of ELF is not meant to erase the demarcation of features that characterize different varieties of English. It is the other way around. ELF well reflects the international currency of English use and is a means to channel diverse varieties to the passage of communication through a language that is mutually intelligible.

\section{Identity Negotiation and Circumstantial Communities of Practice}

\subsection{Imagined Identities and Communities}

Language learners' identity is constructed, as it were, in social and cultural communities, and is also formed in "imagined communities" (Norton, 2001, p. 165), communities lying beyond the realm of immediate communities (Norton, 1997, 2000, 2001). Distinct from communities that are concretely tangible and accessible (i.e., home, school, neighborhood, workplace, etc.), imagined communities (e.g., nationhood or transitional communities) are another source of community where learners' transitional identities are shaped and their learning opportunities affected by their imaginative engagement in learning (Norton, 2001; Kanno \& Norton, 2003). This is fully elaborated in Norton's (2001) in-depth interviews and participant observation of the learning trajectories of two immigrant language learners in Canada, Katarina and Felicia, and their shifting language practices and transitional identities. In earlier studies on how communities of imagination were established, many researchers (e.g., Wenger, 1998; Kinginger, 2004) found that language learners engaging in different environments might negotiate diverse facets of identity in learning the target language. The negotiation of identity might be formed through the agency of language learning experiences that fused with imaginative engagement. The imagined membership in communities with which they affiliated contributed to their struggles to invest in language learning and also in the identity they assumed in imagined communities (Norton, 2000, 2001; Norton \& Toohey, 2002, 2011).

\subsection{Vygotskian Sociocultural Theories in SLA}

In psychologically-oriented (e.g., Lantolf, 2000; Lantolf \& Thorne, 2006) and sociologically-oriented (e.g., Toohey, 2000; Toohey \& Norton, 2010) studies, SLA researchers have brought to light the polymorphous nature of language learning occurring in different community contexts. Vygotskian sociocultural approaches to SLA, in particular, marked the watershed between theories that see language learners as internally mediated and those that consider learners as active members of social activities. According to Vygotsky's $(1981,1987)$ views on the social nature of language learning as a dynamic tool experienced by learners, the cognitive process of language development (i.e., the process of acquiring knowledge and skills) occurs at both internal and external levels. Modifying Vygotsky's argument, Atkinson (2002) argues that at different stages of development, language learning is "mutually, simultaneously, and co-constitutively in the head and in the world" (p. 538). Namely, language learning is an internal process (cognitive practice) that intersects with external approaches (cultural and social practice). In Vygotskian sociocultural theories in SLA, learners use cultural and symbolic tools to engage in a variety of social interaction practices (Lantolf, 2000). Rogoff (2003) aptly noted that learning is "changing participation in the sociocultural activities of a community, which also changes" (p. 368).

In light of this interactional dynamics, identity is articulated through micro and macro components as well as the interplay of both. Block (2003) also sheds light on the relationship between individuals and their communities, arguing that active negotiation and collaborative communicative practice are at the heart of 
Sociolinguistic approaches to identity negotiation and language learning

language acquisition and learning. Thus, language use represents the intersection of communicative modalities and environmental influences, and takes place in contact situations and environments in which they are embedded (Lantolf \& Thorne, 2006; Atkinson, et al., 2007).

\subsection{Functional Linguistics Perspectives}

This study particularly drew on Bucholtz and Hall's (2005) conception of functional and interactional linguistics. In L2 learner struggles to develop symbolic competence, their interactional practice intersects with sociocultural, linguistic, and community contexts. As such, constructs of interactional identities emerge in discourse where interactional negotiation takes place in tandem with a variety of linguistic interactions. As opposed to a static and fixed construct formed in an a priori fashion, sociocultural identity circulates in discourse contexts and is emergent in interaction. Building on macrosociological theory of identity, sociocultural linguistic work zooms in on identity and community, where language, culture, and society are actively at play. The interactional dimensions of language use have developed into a more complex level with the global currency of ELF and its interaction with WEs growing in the train of postmodern globalization. Situational resources and social negotiations in communicative contexts have become more fluid in interactional contexts. In view of the language ecology in bilingual and multilingual settings, homogeneous community perspectives are bereft of adapting to changes wrought by transitional affiliations, fluid social boundaries, and the blurred space distinctions in global communicative contexts (Kramsch, 2002; Larsen-Freeman, 2002).

In speech communities where speakers do not belong to identical geographical boundary, a lingua franca serves as a vehicle for communication between L2/FL speakers and other non-native speakers (Canagarajah, 2007). While they might practice their own languages and cultures in their immediate communities, they are connected in contexts of transitional communicative practice of their shared L2. As these communicative acts and identities may be in the making of social interaction in interpersonal activities, L2 learners inevitably need to practice the language in interaction with other members in community contexts. Brutt-Griffler (2002) appropriately refers macro-acquisition to describing the interactive linguistic relationship between individuals and communities with which they are affiliated. Due to different social circumstances, the meaning of a single speech act may stretch beyond the local discourse and culture. This type of linguistic and cultural pluralism is constructed with the practice of language and the negotiation of identity. A synergy is then developed through the agency of the dynamic nature of community and identity that is negotiated accordingly.

\subsection{A Circumstantiality Perspective on the Community of Practice}

In a similar vein, this study also argues that the sense of community to L2 learners may extend well beyond the confines of their immediate communities. The porous borders of globalized communities could be viewed as a two-way street. While L2 learners are constructing their sociocultural identity in their immediate communities, their identity is concurrently being shaped in collaboration with potential participants in their community circles in casual and fluid movements across national and linguistic boundaries. This is similar to the social ecology in which intergroup interactions also form their identity by means of interactional discourse. These community circles, usually composed of speakers of different varieties, also contribute circumstantially to the negotiation and reconstruction of L2 learners' identity, a mutual construct as changing over time. These circumstantial communities are formed as a result of fortuitous circumstances (cf. Stephen \& Schechter, 1980). Within a constellation of communities of interconnected practices, ecological perspectives on intercultural communication might come in handy. In communities where reciprocal exchanges mushroom, demands for communicative competence rise as social walls of these communities fall. In light of the complex ecology of community circles in multilingual and multicultural environments, potential community members not affiliated to L2 learners' community could also impinge on their community practice.

This study argues for a perspective on the "circumstantiality" of language learning and the relationship between immediate and potential community circles in which language learners engage as not only porous but 
also circumstantial. In increasingly globalized contexts in which we live, both imagined and circumstantial communities have implications for language teaching and learning of bilinguals and multilinguals. In these communities, ecological perspectives are central to understanding how language learners tap rich linguistic resources for identity construction, which in turn allows them to actively participate in activities situated in classrooms and sociocultural contexts and thus promotes their language learning (cf. Thomashow, 1996; Brown, 2002).

\section{Conclusion}

As has been discussed earlier, the global use of English has made it necessary to employ sociocultural approaches to understanding the ecology of bilingualism and multilingualism, and the linguistic repertoires available to bilinguals and multilinguals (Phillipson, 2000). The existential sense of identity as a complex social, cultural, and interactional phenomenon has informed the identity work conducted via various approaches and methodologies. On account of the growing trend of globalization, there are several implications for second and foreign language acquisition and pedagogy.

First, a broad range of interactions may affect the process of identity construction. In bilingual and multilingual communities today, active members of a sociocultural community are no longer restricted to local social groupings. From a communication perspective, distinctions among affiliated members, potential participants, casual visitors are being blurred. This linguistic, social, and cultural fluidity across borders may also circumstantially have an effect on the local community that is not enclosed. The influence wrought by viable inter-community communication also shapes language learners' identity in a mutual way.

Second, as learners' social world does not revolve around a single axis, language learning is rendered socioculturally dependent by virtue of the complex nature of communities of practice. As such, their identity construction entails learners' active participation both in their local social practices and in wider social worlds. Due to increasing globalization and the growth of English-speaking population, opportunities of interlinguistic and intercultural communication multiply across different Circles of English. Thus, it is critical that future inquiry on second and foreign language learning and use be examined through a wider lens of sociocultural linguistics that places language learning, usually conceived as primarily cognitive processes, in real-life situations.

A final implication is that in pedagogical matters, language teachers should be aware that mutual intelligibility governs all forms of communication and is second to none in the teaching and learning of English. It is essential that language teaching professionals recognize that students may express their sociocultural identity through a social world in which their identity is constructed and transformed. Further, as Mannheim and Tedlock (1995) argue, culture emerges through discourse practices. Thus, cultural and communicative practices both inside and outside the classroom have a bearing on the construction of identity. There is a particular need for teachers to understand how language teaching and learning interact with multiple dimensions of learners' identity. Embedded in mundane contexts, collaborative communication helps form their transitional identity inside and outside the classroom.

When the sociocultural processes of language learning are in close focus, the development of communicative and symbolic competence would be of considerable importance to language learning. Due to the globalized contexts in which language learning takes place, language teachers should employ approaches, adaptive to the currency of the social world outside the classroom, to facilitating teaching so as to develop the learning potential of bilingual and multilingual students.

Acknowledgement: I would like to express my gratitude to the following people who provided me with valuable feedback and assistance: Chris Merkelbach, Janette Yuvienco, I-Chin Chiang, and my anonymous reviewers. 


\section{References:}

Anderson, B. (1991). Imagined communities: Reflections on the origin and spread of nationalism (revised ed.). New York: Verso. <http://dx.doi.org/10.1111/1540-4781.00159>

Atkinson, D. (2002). Toward a sociocognitive approach to second language acquisition. Modern Language Journal, 86(4), 525-545. <http://dx.doi.org/10.1111/j.1540-4781.2007.00539.x>

Atkinson, D., Churchill, E., Nishino, T., \& Okada, H. (2007). Alignment and interaction in a sociocognitive approach in second language acquisition. Modern Language Journal, 91, 169-188.

Bartlett, L. (2007). To seem and to feel: Situated identities and literacy practices. Teacher's College Record, 109(1), 51-69.

Bayley, R., \& Schechter, S. R. (Eds.) (2003). Language socialization in bilingual and multilingual societies. Clevedon, UK: Multilingual Matters

Block, D. (2003). The social turn in second language acquisition. Edinburgh, UK: Edinburgh University Press.

Block, D. (2006). Multilingual identities in a global city: London stories. London: Palgrave.

Block, D. (2007a). The rise of identity in SLA research, post Firth and Wagner (1997). The Modern Language Journal, 91(5), 863-876. <http://dx.doi.org/10.1111/j.1540-4781.2007.00674.x>

Block, D. (2007b). Second language identities. London: Continuum.

Block, D. (2008). Language education and globalization. Encyclopedia of language and education (2nd ed.), Vol. 1. In S. May \& N. H. Hornberger (Eds.), Language policy and political issues in education (pp. 31-43). New York: Springer.

Breen, M., \& Candlin, C. (1980). The essentials of a communicative curriculum in language teaching, Applied Linguistics, 1(1), 89-112. <http://dx.doi.org/10.1093/applin/1.2.89>

Brown, S. L. (2002). Intentional community: An anthropological perspective. New York: State University of New York Press.

Brutt-Griffler, J. (2002). World English: A study of its development. Clevedon, England: Multilingual Matters.

Bucholtz, M. K. (2005). Identity and interaction: A sociocultural linguistic approach. Discourse Studies, 7 , 585-614. <http://dx.doi.org/10.1177/1461445605054407>

Canagarajah, S. (2006).Changing communicative needs, revised assessment objectives: Testing English as an international language. Language Assessment Quarterly, 3(3), 229-242.

$<$ http://dx.doi.org/10.1207/s15434311laq0303_1>

Canagarajah, S. (2007). Ecology of global English. International Multilingual Research Journal, 1(2), 89-100. <http://dx.doi.org/10.1080/15257770701495299>

Chambers, J. (2004). Dynamic typology and vernacular universals. In B. Kortmann (Ed.), Dialectology meets typology: Dialect grammar from a cross-linguistic perspective (pp. 124-145). Berlin: Mouton de Gruyter.

Crystal, D. (2003). English as a global language. (2nd ed.). Cambridge, England: Cambridge University Press. $<$ http://dx.doi.org/10.1017/CBO9780511486999>

Dornyei, Z., \& Skehan, P. (2005). Individual differences in second language learning. In C. Doughty and M. Long (Eds.), The handbook of second language acquisition (pp. 589-625). Oxford, Blackwell.

Dulay, H. C., Burt, M. K., \& Krashen, S. (1982). Language two. New York: Oxford University Press.

Duff, P. (2002). The discursive co-construction of knowledge, identity, and difference: An ethnography of communication in the high school mainstream. Applied Linguistics, 23, 289-322. <http://dx.doi.org/10.1093/applin/23.3.289>

Firth, A. (1996). The discursive accomplishment of 'normality:' On lingua franca English and conversation analysis. Journal of Pragmatics, 26, 237-259. <http://dx.doi.org/10.1016/0378-2166(96)00014-8>

Gardner, R. C. (1988). The socio-educational model of second language learning: Assumptions, findings and issues. Language Learning, 38, 101-126. <http://dx.doi.org/10.1111/j.1467-1770.1988.tb00403.x>

Gass, S., \& Varonis, E. (1986). Sex differences in non-native speaker-nonnative speaker interactions. In R. Day (Ed.), Talking to learn: Conversation in second language acquisition (pp. 327-351). Rowley, MA: Newbury House. 
Goldstein, H. (1987). Multilevel models in educational and social research. London, Griffin; New York, Oxford University Press.

Haggis, T. (2004). Meaning, identity and 'motivation': expanding what matters in understanding learning in higher education. Studies in Higher Education, 29(3), 335-352.

<http://dx.doi.org/10.1080/03075070410001682538>

Heller, M. (2007a). Bilingualism as ideology and practice. In M. Heller (Ed.), Bilingualism: A social approach (pp.1-22). New York: Palgrave Macmillan. <http://dx.doi.org/10.1057/9780230596047>

Hornberger, N. H. (2007). Biliteracy, transnationalism, multimodality, and identity: Trajectories across time and space. Linguistics and Education, 18(3-4), 325-334. <http://dx.doi.org/10.1016/j.linged.2007.10.001>

Kachru, B. B. (1988). Teaching world Englishes. ERIC/CLL News Bulletin, 12(1), 1-8.

Kachru, B. B. (Ed.) (1992). The other tongue: English across cultures (2nd ed.). Urbana, Il: University of Illinois Press.

Kachru, B. B. (1997). World Englishes and English-using communities. Annual Review of Applied Linguistics, 17, 66-87. <http://dx.doi.org/10.1017/S0267190500003287>

Kachru, Y., \& Nelson, C.L. (2006). World Englishes in Asian contexts. Hong Kong: Hong Kong University Press.

Kanno, Y., \& Norton, B. (Eds.) (2003). Imagined communities and educational possibilities. Journal of Language, Identity, and Education, 2(4), (special issue).

Kinginger, C. (2004). Alice doesn't live here anymore: Foreign language learning and identity (re)construction. In A. Pavlenko \& A. Blackledge (Eds.), Negotiation of identities in multilingual contexts (pp. 219-242). Clevedon: Multilingual Matters.

Kirkpatrick, A. (2010). English as a lingua franca in ASEAN: A multilingual model. Hong Kong: Hong Kong University Press. <http://dx.doi.org/10.5790/hongkong/9789888028795.001.0001>

Kramsch, C. (Ed.) (2002). Language acquisition and language socialization: Ecological perspectives. London: Continuum.

Lantolf, J. P. (Ed.) (2000). Sociocultural theory and second language learning. Oxford, UK: Oxford University Press.

Lantolf, J. P., \& Thorne, S.L. (2006). Sociocultural theory and the sociogenesis of second language development. New York: Oxford University Press.

Larsen-Freeman, D. (1997). Chaos/complexity science and second language acquisition. Applied Linguistics, 18, 141-165. <http://dx.doi.org/10.1093/applin/18.2.141>

Larsen-Freeman, D. (2002). Language acquisition and language use from a chaos/complexity theory perspective. In C. Kramsch (Ed.), Language acquisition and language socialization (pp. 33-46). London: Continuum.

Lave, J., \& Wenger, E. (1991). Situated learning: Legitimate peripheral participation. Cambridge, England: Cambridge University Press.

Li, D. C. S. (2006). Chinese as a lingua franca in greater China. Annual Review of Applied Linguistics, 26, 149-176. <http://dx.doi.org/10.1017/S0267190506000080>

Mannheim, B., \& Tedlock, D. (1995). Introduction. In D. Tedlock \& B. Mannheim (Eds.), The dialogic emergence of culture (pp. 1-32). Urbana: University of Illinois Press.

Martin-Jones, M., \& Heller, M. (1996). Introduction to the special issues on education in multilingual settings: Discourse, identities, and power. Part 1. Constructing legitimacy. Linguistics and Education, 8, 3-16. $<$ http://dx.doi.org/10.1016/S0898-5898(96)90003-0>

McLellan, J., \& David, M. (2007). A review of code switching research in Malaysia and Brunei Darussalam. In D. Prescott (Ed.), English in Southeast Asia (pp. 93-117). Newcastle upon Tyne: Cambridge Scholars Publishing.

McGroarty, M. (2006). Editor's introduction: Lingua franca languages. Annual Review of Applied Linguistics, 26, vii-xi. <http://dx.doi.org/10.1017/S0267190506000018>

McKay, S. L., \& Bokhorst-Heng, W. D. (2008). International English in its sociolinguistic contexts: Towards a socially sensitive EIL pedagogy. New York: Routledge. 
Sociolinguistic approaches to identity negotiation and language learning

Menard-Warwick, J. (2005). Both a fiction and an existential fact: Theorizing identity in second language acquisition and literacy studies. Linguistics and Education, 16(3), 253-274. $<$ http://dx.doi.org/10.1016/j.linged.2006.02.001>

Murphy, M. L. (1997). The elusive bisexual: Social categorization and lexico-semantic change. In A. Livia \& K. Hall (Eds.), Queerly phrased: Language, gender, and sexuality (pp. 35-57). New York: Oxford University Press.

Norton, B. (Ed.) (1997). Language and identity. TESOL Quarterly, 31(3), (special issue).

Norton, B. (2000). Identity and language learning: Gender, ethnicity and educational change. Harlow, UK: Pearson Education/Longman.

Norton, B. (2001). Non-participation, imagined communities, and the language classroom. In M. Breen (Ed.), Learner contributions to language learning: New directions in research (pp. 159-171). Harlow, England: Pearson Education.

Norton, B., \& Toohey, K. (2002). Identity and language learning. In R. Kaplan (Ed.), The Oxford handbook of applied linguistics (pp. 115-123). Oxford, England: Oxford University Press.

Norton, B., \& Toohey, K. (2011). Identity, language learning, and social change. Language Teaching, 44(4), 412-446. <http://dx.doi.org/10.1017/S0261444811000309>

Pavlenko, A., \& Blackledge, A. (Eds.). (2004). Negotiation of identities in multilingual settings (pp. 219-242). Clevedon, UK: Multilingual Matters

Peirce, B. N. (1995). Social identity, investment, and language learning. TESOL Quarterly, 29(1), 9-31. $<$ http://dx.doi.org/10.2307/3587803>

Phan, L. H. (2008). Teaching English as an international language: Identity, resistance and negotiation. Clevedon: Multilingual Matters.

Phillipson, R. (Ed.) (2000). Rights to language: Equity, power, and education. Mahwah, NJ: Lawrence Erlbaum.

Quirk, R. (1985). The English language in a global context. In R. Quirk \& H.G. Widdowson (Eds.), English in the world. Teaching and learning the languages and the literatures. Cambridge University Press.

Quirk, R. (1990). Language varieties and standard language. English Today, 21, 3-21. $<$ http://dx.doi.org/10.1017/S0266078400004454>

Ricento, T. (2005). Considerations of identity in L2 learning. In E. Hinkel (Ed.), Handbook of research on second language teaching and learning (pp. 895-911). Mahwah, NJ: Lawrence Erlbaum.

Rogoff, B. (2003). The cultural nature of human development. Oxford, UK: Oxford University Press.

Sacks, H. (1995). Lectures on Conversation. 2 vols. Oxford: Basil Blackwell. $<$ http://dx.doi.org/10.1002/9781444328301>

Stephen L., \& Schechter, S. L. (1980). The founding of American local communities: A study of covenantal and other forms of association. Publius, 10(4), Covenant, Polity, and Constitutionalism, 165-185.

Thomashow, M. (1996). Ecological identity: Becoming a reflective environmentalist. Massachusetts : The MIT Press.

Thomason, S. G. (2009). Why universals versus contact-induced change. In M. Filppula, J. Klemola, \& H. Paulasto (Eds.), Vernacular universals and language contacts: Evidence from varieties of English and beyond (pp. 349-364). London: Routledge.

Toohey, K. (2000). Learning English at school: Identity, social relations and classroom practice. Clevedon, UK: Multilingual Matters.

Toohey, K., \& Norton, B. (2010). Language learner identities and sociocultural worlds. In R. B. Kaplan (Ed.), The Oxford handbook of applied linguistics (2nd ed.). New York: Oxford University Press, 178-188.

Vygotsky, L. S. (1981). The instrumental method in psychology. In J.V. Wertsch (Ed.), The concept of acticity in Soviet psychology. Armonk NY: M.E. Sharpe.

Vygotsky, L. S. (1987). The collected works of L.S. Vygotsky: Vol. 1. Problems of general psychology (including the volume Thinking and speech). (N. Minick, trans.). New York: Plenum.

Watson-Gegeo, K. A. (2004). Mind, language, and epistemology: Toward a language socialization paradigm for SLA. The Modern Language Journal, 88, 331-350.

<http://dx.doi.org/10.1111/j.0026-7902.2004.00233.x> 
Jou, Y. S.

Wenger, E. (1998). Communities of practice: Learning, meaning, and identity. Cambridge: Cambridge University Press.

Widdowson, H. (1994). The ownership of English. TESOL Quarterly, 28(2), 377-389. <http://dx.doi.org/10.2307/3587438>

Zuengler, J. (1989). Identity and IL development and use. Applied Linguistics, 10(1), 80-96. <http://dx.doi.org/10.1093/applin/10.1.80>

Zuengler, J., \& Miller, E. (2006). Cognitive and sociocultural perspectives: Two parallel worlds? TESOL Quarterly, 40, 35-58. <http://dx.doi.org/10.2307/40264510> 